\title{
Prevalence of Collar Rot of Tomato Caused by Sclerotium rolfsii (Sacc.) under the Red and Lateritic Zone of West Bengal, India
}

\author{
Asish Mahato, Mohan Kumar Biswas" and Suman Patra
}

\author{
Department of Plant Protection, Palli-Siksha Bhavana, Visva-Bharati, Sriniketan, \\ West Bengal-731236, India \\ *Corresponding author
}

\author{
A B S T R A C T
}

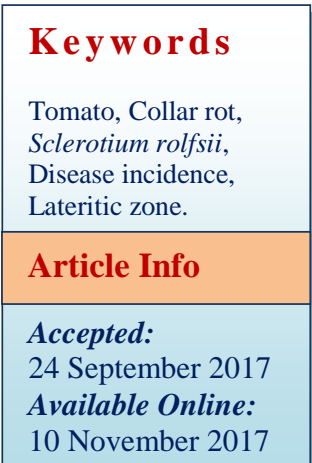

10 November 2017
Tomato (Solanum lycopersicon L.) a member of the family Solanaceae, is the world's largest vegetable crop after potato and sweet potato. Diseases of tomato act as the chief limiting factor to its economic production. Recently, the collar rot caused by Sclerotium rolfsii is becoming sever disease of tomato in India. Crop Losses up to 30 per cent due to collar rot disease have been reported by many researchers in this crop. Hence to get a preliminary idea regarding the incidence level and pattern of prevalence of the disease in the agro-ecological condition of undulating red and lateritic zone of West Bengal, a roving survey was conducted at different locations of the aforesaid agro climatic zone during the crop growing season of 2014-15 and 2015-16. The pooled analysis of two years data revealed that disease incidence was ranged from 7.61 to $21.79 \%$ in this zone and the Purulia district had maximum level of disease incidence ranging from 13.14 to $21.79 \%$ followed by Bankura districts 11.90 to $16.64 \%$, Birbhum district 9.75 to $17.73 \%$, Burdwan district 7.61 to $14.54 \%$. Paschim Medinipur district was noticed with less incidence levels ranging from 9.08 to $9.51 \%$. This study provided an elementary idea about the disease incidence pattern in this zone as well as paved the path for seeking resistance sources under local conditions and recommendation of proper farming practices to combat the drastic effects of collar rot disease.

\section{Introduction}

Tomato (Solanum lycopersicon L.) a member of the family Solanaceae, is the most popular and high-value vegetable crop in the world because of its taste, color and high nutritive value and also for its diversified use. It is the world's largest vegetable crop after potato and sweet potato. Due to its extensive cultivation in non-traditional areas, several biotic and abiotic factors have emerged as a major constraint in its successful cultivation. Among the biotic factors, diseases i.e., collar rot (Sclerotium rolfsii), damping off (Pythium spp.), early blight (Alternaria solani), fruit rot (Phytophthora nicotianae), bacterial wilt (Ralstonia solanacearum), Bacterial fruit canker: (Clavibacter michiganense subsp. Michiganense), Rhizoctonia root rot (Rhizoctonia solani), Tomato spotted wiltTomato Spotted Wilt Virus (TSWV), Tomato Mosaic (Tomato mosaic virus), Root knot nematode (Meloidogyne sp), little leaf (phytoplasmal) are the major diseases of Tomato (Meah, 2003). But recently, the collar rot caused by Sclerotium rolfsii is becoming 
sever disease of tomato in India. It caused 30 per cent of crop loss in Tomato (Thiribhuvanamala et al., 1999). Banyal et al., (2008) reported collar rot caused by Sclerotium rolfsii (Corticium rolfsii) is one of the major threats in Himachal Pradesh, India, with an incidence of $10-45 \%$. The disease is distributed in tropical and sub-tropical regions of the world where high temperatures prevail. Sclerotium rolfsii, the causal agent of collar/foot rot of many crops (Aycock, 1966) having a wider host range (Talukdar, 1974 and Bhattacharrya et al., 1977) attracted the attention of plant pathologist and professional researcher throughout the world. The pathogen is known to cause diseases of cereals, pulses, oil crops, potatoes, vegetables, ornamentals, and nursery seedlings of fruits and forest trees (Bertus, 1929). The pathogen is a soil inhabitant, very aggressive nature, attacks the collar portion of plant, which ultimately leads to its death. The infection leads to the drying of lower leaves and eventually the whole plant dries giving a typical symptom of wilting. The collar rot of tomato may occur at any growth stage of the plant (Begum et al., 1985). The disease has been reported by many workers in different agro climatic zone of West Bengal. But accurate information of natural incidence level of the disease particularly in the undulating red and lateritic zone of West Bengal is scanty. Inadequate knowledge about the incidence level of the disease, their distribution pattern etc. leads the use of chemicals indiscriminately. Therefore the present study was carried to find out the occurrence and distribution pattern of collar rot disease of tomato in the agro-ecological condition of undulating red and lateritic zone of West Bengal.

\section{Materials and Methods}

To estimate the natural incidence of collar rot disease of tomato under the agro-ecological condition of undulating red and lateritic zone of West Bengal, surveys were carried out during the crop growing season of 2014-15 and 2015-16 in different district of undulating red and lateritic regions of West Bengal which include part of Birbhum, Bankura, Purulia, Burdwan and Paschim Medinipur, where tomato crops was cultivated extensively by the farmers.

In each place, field of more or less uniform size was selected at random and observation on the incidence of the diseases was recorded. Percent disease incidence was calculated by using the following formula.

Number of plants showing wilting symptom

Percent Disease Incidence = ----------- X 100

Total number of plants

\section{Results and Discussion}

To obtain information on the natural incidence of collar rot of tomato, surveys were conducted during the growing season (November' 2014-April' 2015 and November' 2015-April' 2016) in different locations of undulating red and lateritic zone of West Bengal i.e. Birbhum, Burdwan, Bankura, Purulia and Paschim Medinipur districts to record the incidence of the disease. The recorded data of disease incidence have been presented in the table 1 and 2 .

It was evident from both the tables that the incidence of collar rot disease of tomato varied with the location and season. The incidence of the collar rot disease ranging from $7.36 \%$ to $21.06 \%$ was obtained during 2014-15 (Table 1) while during the year 2015-16 it was ranging between7.86 \% to $22.52 \%$ (Table 2). The highest disease incidence of $17.75 \%$ was found in district Purulia followed by district Bankura $14.54 \%$, Birbhum district $13.91 \%$, Burdwan District 
$10.48 \%$ and least incidence was observed in Paschim Medinipur district $8.87 \%$ during the year 2014-15 (Table 1 and Fig. 1). While, more or less similar trend was observed during the year 2015-16 with highest incidence in district Purulia on $18.00 \%$ followed by Bankura district on $14.72 \%$, Birbhum district $13.97 \%$, Burdwan District $11.04 \%$ and least incidence in Paschim Medinipur district $8.98 \%$ (Table 2 and Fig.
1). Among the locations surveyed, disease incidence was highest at Nanduara village of Raghunathpur-1 block under Purulia district during both the years of survey $(21.06 \%$ and $22.52 \%$ during 2014-15 and 2015-16 respectively) while, it was lowest on $7.36 \%$ and $7.86 \%$ at Gobindapur village of Pandebeswar block, under Burdwan district during 2014-15 and 2015-16 respectively.

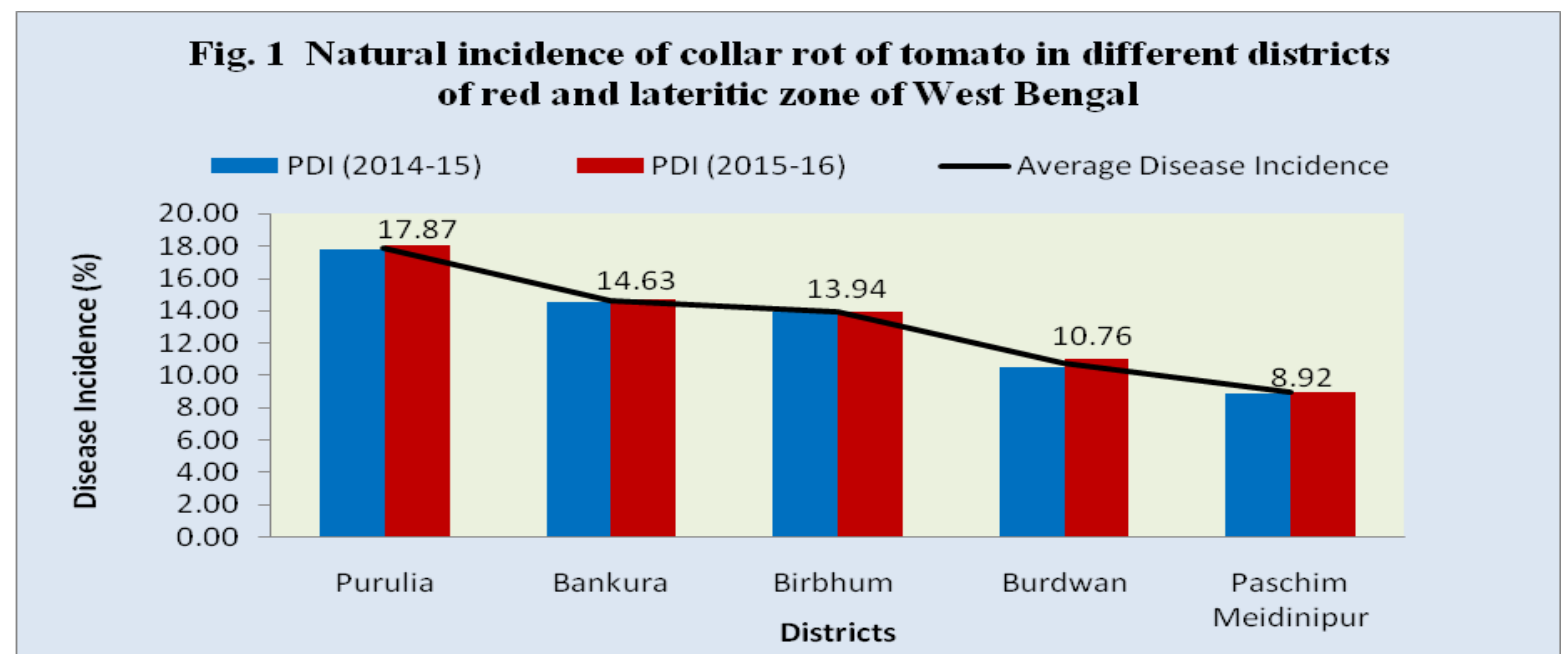

Photo Plate.1 Categorization of districts of red and lateritic zone of West Bengal based on prevalence of collar rot of tomato caused by Sclerotium rolfsii. (+) sign refers to the degree of prevalence of disease with $(+++++)$ for maximum and $(+)$ for minimum prevalence and subsequent degree of prevalence accordingly as per no. of (+) sign

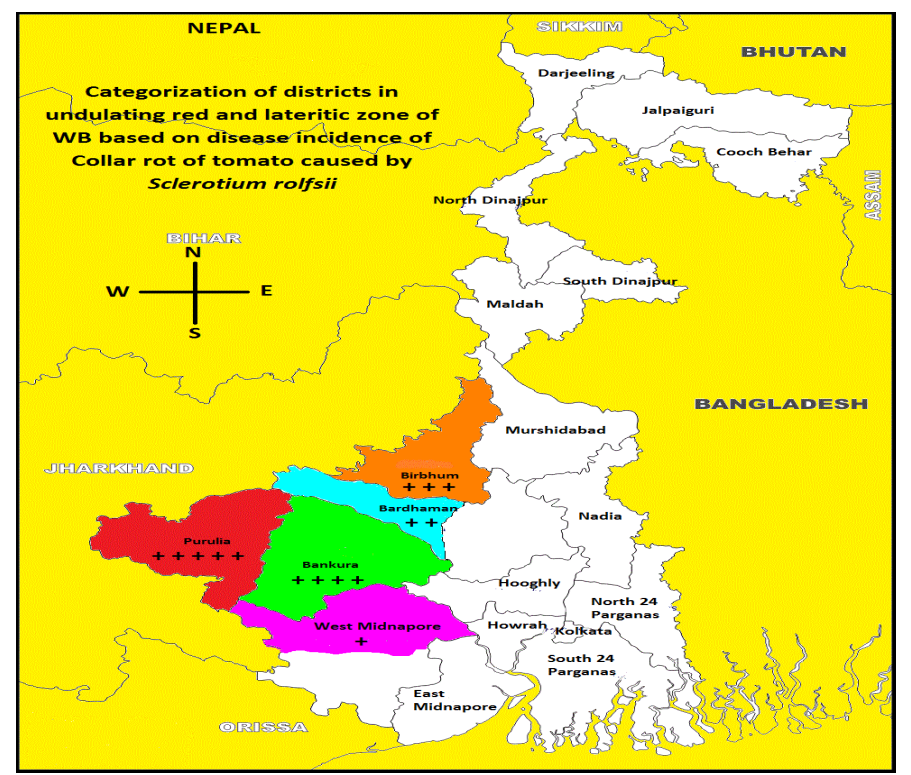


Table.1 Natural incidence of collar rot of tomato in different locations of red and lateritic zone of West Bengal during 2014-15

\begin{tabular}{|c|c|c|c|c|c|c|}
\hline $\begin{array}{l}\text { S. } \\
\text { No }\end{array}$ & District & Block & Village & $\begin{array}{c}\text { No of } \\
\text { Field } \\
\text { Surveyed } \\
\end{array}$ & $\begin{array}{c}\text { Disease } \\
\text { Incidence }\end{array}$ & $\begin{array}{c}\text { District wise } \\
\text { Average Disease } \\
\text { Incidence } \\
\end{array}$ \\
\hline 1 & \multirow{3}{*}{ Purulia } & Hura & Daldali & 4 & 13.64 & \multirow{3}{*}{17.75} \\
\hline 2 & & Manbajar & Nathurdi & 5 & 18.54 & \\
\hline 3 & & Raghunathpur 1 & Nanduara & 8 & 21.06 & \\
\hline 4 & \multirow{3}{*}{ Bankura } & Gangalalghati & Dangjuria & 6 & 16.52 & \multirow{3}{*}{14.54} \\
\hline 5 & & Chatna & Chatna & 4 & 15.36 & \\
\hline 6 & & Borjora & Borjora & 9 & 11.75 & \\
\hline 7 & \multirow{3}{*}{ Birbhum } & Ilambajar & khayerbani & 4 & 9.65 & \multirow{3}{*}{13.91} \\
\hline 8 & & Labpur & Labpur & 6 & 14.75 & \\
\hline 9 & & Bolpur Sriniketan & Benuria & 7 & 17.34 & \\
\hline 10 & \multirow{3}{*}{ Burdwan } & Raniganj & Belebathan & 5 & 14.04 & \multirow{3}{*}{10.48} \\
\hline 11 & & Pandebeswar & Gobindapur & 4 & 7.36 & \\
\hline 12 & & Salanpur & Salanpur & 6 & 10.03 & \\
\hline 13 & \multirow{3}{*}{$\begin{array}{l}\text { Paschim } \\
\text { Medinipur }\end{array}$} & Gorbetha & Garberia & 6 & 9.48 & \multirow{3}{*}{8.87} \\
\hline 14 & & Jharagram & Jharagram & 5 & 9.02 & \\
\hline 15 & & Binpur & Binpur & 4 & 8.10 & \\
\hline
\end{tabular}

Table.2 Natural incidence of collar rot of tomato at different locations of red and lateritic zone of West Bengal during 2015-16

\begin{tabular}{|c|c|c|c|c|c|c|}
\hline $\begin{array}{l}\text { S. } \\
\text { No }\end{array}$ & District & Block & Village & $\begin{array}{c}\text { No of } \\
\text { Field } \\
\text { Surveyed }\end{array}$ & $\begin{array}{c}\text { Disease } \\
\text { Incidence }\end{array}$ & $\begin{array}{c}\text { District wise } \\
\text { Average } \\
\text { Disease } \\
\text { Incidence }\end{array}$ \\
\hline 1 & \multirow{3}{*}{ Purulia } & Hura & Daldali & 4 & 12.64 & \multirow{3}{*}{18.00} \\
\hline 2 & & Manbajar & Nathurdi & 5 & 18.84 & \\
\hline 3 & & Raghunathpur 1 & Nanduara & 8 & 22.52 & \\
\hline 4 & \multirow{3}{*}{ Bankura } & Gangalalghati & Dangjuria & 6 & 16.75 & \multirow{3}{*}{14.72} \\
\hline 5 & & Chatna & Chatna & 4 & 15.36 & \\
\hline 6 & & Borjora & Borjora & 9 & 12.05 & \\
\hline 7 & \multirow{3}{*}{ Birbhum } & Ilambajar & khayerbani & 4 & 9.85 & \multirow{3}{*}{13.97} \\
\hline 8 & & Labpur & Labpur & 6 & 13.95 & \\
\hline 9 & & Bolpur Sriniketan & Benuria & 7 & 18.12 & \\
\hline 10 & \multirow{3}{*}{ Burdwan } & Raniganj & Belebathan & 5 & 15.04 & \multirow{3}{*}{11.04} \\
\hline 11 & & Pandebeswar & Gobindapur & 4 & 7.86 & \\
\hline 12 & & Salanpur & Salanpur & 6 & 10.23 & \\
\hline 13 & \multirow{3}{*}{$\begin{array}{l}\text { Paschim } \\
\text { Medinipur }\end{array}$} & Gorbetha & Garberia & 6 & 9.53 & \multirow{3}{*}{8.98} \\
\hline 14 & & Jharagram & Jharagram & 5 & 9.14 & \\
\hline 15 & & Binpur & Binpur & 4 & 8.26 & \\
\hline
\end{tabular}


Table.3 Natural incidence of collar rot of tomato in different districts of red and lateritic zone of West Bengal (Pooled analysis)

\begin{tabular}{|c|c|c|c|c|c|c|c|}
\hline \multirow{2}{*}{ S.No } & \multirow{2}{*}{ District } & \multirow{2}{*}{ Block } & \multirow{2}{*}{ Village } & \multicolumn{2}{|c|}{ Disease Incidence } & \multirow{2}{*}{$\begin{array}{l}\text { Average } \\
\text { disease } \\
\text { Incidence }\end{array}$} & \multirow{2}{*}{$\begin{array}{l}\text { District } \\
\text { wise } \\
\text { disease } \\
\text { incidence }\end{array}$} \\
\hline & & & & 2014-15 & 2015-16 & & \\
\hline 1 & \multirow{3}{*}{ Purulia } & Hura & Daldali & 13.64 & 12.64 & 13.14 & \multirow{3}{*}{17.87} \\
\hline 2 & & Manbajar & Nathurdi & 18.54 & 18.84 & 18.69 & \\
\hline 3 & & Raghunathpur 1 & Nanduara & 21.06 & 22.52 & 21.79 & \\
\hline 4 & \multirow{3}{*}{ Bankura } & Gangalalghati & Dangjuria & 16.52 & 16.75 & 16.64 & \multirow{3}{*}{14.63} \\
\hline 5 & & Chatna & Chatna & 15.36 & 15.36 & 15.36 & \\
\hline 6 & & Borjora & Borjora & 11.75 & 12.05 & 11.90 & \\
\hline 7 & \multirow{3}{*}{ Birbhum } & Ilambajar & khayerbani & 9.65 & 9.85 & 9.75 & \multirow{3}{*}{13.94} \\
\hline 8 & & Labpur & Labpur & 14.75 & 13.95 & 14.35 & \\
\hline 9 & & Bolpur Sriniketan & Benuria & 17.34 & 18.12 & 17.73 & \\
\hline 10 & \multirow{3}{*}{ Burdwan } & Raniganj & Belebathan & 14.04 & 15.04 & 14.54 & \multirow{3}{*}{10.76} \\
\hline 11 & & Pandebeswar & Gobindapur & 7.36 & 7.86 & 7.61 & \\
\hline 12 & & Salanpur & Salanpur & 10.03 & 10.23 & 10.13 & \\
\hline 13 & \multirow{3}{*}{$\begin{array}{l}\text { Paschim } \\
\text { Midnapur }\end{array}$} & Gorbetha & Garberia & 9.48 & 9.53 & 9.51 & \multirow{3}{*}{8.92} \\
\hline 14 & & Jharagram & Jharagram & 9.02 & 9.14 & 9.08 & \\
\hline 15 & & Binpur & Binpur & 8.10 & 8.26 & 8.18 & \\
\hline
\end{tabular}

While comparison of the incidence level of collar rot disease in five districts, the pooled analysis (Table 3 and Fig. 1) indicated that the Purulia district had maximum level of disease incidence ranging from 13.14 to $21.79 \%$ followed by Bankura districts 11.90 to 16.64 $\%$, Birbhum district 9.75 to $17.73 \%$, Burdwan district 7.61 to $14.54 \%$. Paschim Medinipur district was noticed with less incidence levels ranging from 9.08 to $9.51 \%$ during seasons under surveyed (Photo plate 1). Higher incidence of collar rot of tomato in Purulia and Bankura districts in comparison to Burdwan, Birbhum and Paschim Medinipur districts was probably due to the higher range of soil and atmospheric temperature which help the pathogen Sclerotium rolfsii for faster multiplication and growth in soil and sandy clay loam soil fulfil the high oxygen demand for survival of sclerotia.

Banyal et al., (2008) reported collar rot of tomato (Sclerotium rolfsii) is one of the major threats in Himachal Pradesh, India, with an incidence of $10-45 \%$. Thiribhuvanamala et al., (1999) observed that 30 per cent of crop loss in tomato was due to $S$. rolfsii. Ingale and Mayee, (1986) reported that 25 per cent of seedling mortality in the cultivar JL-24 of Groundnut at Parbhani due to $S$. rolfsii. Naidu (2000) reported that $S$. rolfsii caused 40-50 per cent mortality in crossandra in Chittoor district of Andhra Pradesh. In Chickpea, upto 30 percent disease incidence reported in Jabalpur by Padole et al., (2009). In Saurashtra, Gujarat, 30-40\% seedling rot reported on garlic (Lukose et al., 2003). Collar rot caused by $S$. rolfsii is the most destructive disease of tomato in Bangladesh (Talukder, 1974). The above information's are in line of the present findings.

The results obtained in this experimental study revealed that the collar rot of tomato caused by Sclerotium rolfsii was prevalent in all the districts of undulating red and lateritic 
agro-climatic zone of West Bengal (India). The district Purulia showed maximum prevalence of collar rot whereas minimum prevalence was recorded in Paschim Medinipur district. The higher range of soil and atmospheric temperature and continuous cultivation of susceptible cultivars over years were responsible for high prevalence of collar rot in these locations. The finding emphasize on seeking new resistance sources under local conditions and encouraging of sowing resistance cultivars by following good management practices.

\section{References}

Aycock, R., 1966. Stem rot and other diseases caused by $S$. rolfsii. Tech. Bull. No.174. Agric. Expt. Station, North Carolina State University, Raleigh. 202 p.

Banyal, D. K., Mankotia, V., and Sugha, S. K., 2008. Integrated Management of Tomato Collar Rot Caused by Sclerotium rolfsii. J Mycol Pl Pathol. 38 (2).

Banyal, D. K., Mankotia, V., and Sugha, S. K., 2008. Soil characteristics and their relation to the development of tomato collar rot caused by Sclerotium rolfsii. Indian Phytopathology. 61(1):103-107.

Begum, S. N., Chowdhury, B. C., and Ahamed, H. U., 1985. Screening of brinjal varieties for resistance to $S$. rolfsii. Abst. 1st National Conf. Plant Pathology, held at Bangladesh Agricultural Research Institute, Joydebpur, Gazipur. 12 p.

Bertus, L. S., 1929. Sclerotium rolfsii in
Cylon. Ann. Royal Botanical Garden Peradeniya XI (2): 173-187.

Bhattacharrya, S. K., Phadtare, S. G., and Sharma, V. C., 1977. Fungal diseases of potato. Recent technology in potato improvement and production. CPRI. Simpla. India. 209-237 p.

Ingale, R. V., and Mayee, C. D., 1986. Efficacy and economics of some management practices of fungal and diseases of groundnut. Journal of Oil Seeds Research. 3: 201-204.

Lukose, C. M., Kadvani, D. L., and Dangaria, C. J., 2003. Bulb and stem rot of garlic and chili. Indian Phytopathology. 56(2): 237.

Meah, M. B., 2003. Integrated management of Eggplant cultivation-1. IPM laboratory, Department of Plant Pathology, Bangladesh Agricultural University, Mymensingh. Bangladesh. 3-15 pp.

Naidu Harinath, 2000. Crossandra - a new host record for Sclerotium rolfsii. Indian Phytopathology. 53: 496-497.

Padole Sachin, Om Gupta and Madhuri Mishra 2009. Variability among isolates of Sclerotium rolfsii Sacc. causing collar rot of chickpea. Journal of Food Legumes. 22(2):127-130.

Talukder, M. J., 1974. Plant diseases in Bangladesh, Bangladesh J. Agril. Res. 1(1): 61-86.

Thiribhuvanamala, G., Rajeswari, E., and Sabitha Doraiswamy 1999. Inoculum levels of Sclerotium rolfsii on the incidence of stem rot in tomato. Madras Agricultural Journal. 86: 334.

\section{How to cite this article:}

Asish Mahato, Mohan Kumar Biswas and Suman Patra. 2017. Prevalence of Collar Rot of Tomato Caused by Sclerotium rolfsii (Sacc.) under the Red and Lateritic Zone of West Bengal, India. Int.J.Curr.Microbiol.App.Sci. 6(11): 3231-3236.

doi: https://doi.org/10.20546/ijcmas.2017.611.378 